


\section{The Notwithstanding Clause, the Charter, and Canada's Patriated Constitution: What I Thought We Were Doing}

\section{Hon. Allan E. Blakeney ${ }^{\star}$}

Professor Whyte, in his article "Sometimes Constitutions are Made in the Streets: the Future of the Charter's Notwithstanding Clause," raises some intriguing points. ${ }^{1} \mathrm{He}$ gives a historical review of the origin of the "notwithstanding" clause as it appears in the Canadian Charter of Rights and Freedoms, ${ }^{2}$ enacted in 1982. In the course of so doing, he appears to propose a distinction between "rights" - those claims which are included in the Charter, and "policies" - those claims which are protected by the activities of the legislative and executive arms of government. This is, I argue, a false dichotomy. It leads to the conclusion that the use of the "notwithstanding" clause can only amount to a suspension of rights in favour of achieving government policy.

In this paper I argue that the framers of the Charter selected specific rights and freedoms for constitutional protection knowing that infringements of those rights by the state would appropriately be dealt with by the courts. The decision to leave other rights out of the Charter was made knowing that those other rights would best be enforced by the legislative, executive, and administrative arms of government. Section 33, the "notwithstanding" clause, was included in the Charter to ensure that the state could, for economic or social reasons, or because other rights were found in the circumstances to be more important, choose to override a Charter-protected right. This involves an acceptance of the idea, which I believe to be correct, that the rights enumerated in the Charter are not more important than other human rights. The belief that the rights enumerated in the Charter are somehow more important than other human rights is unsound. The Charter should not be regarded as creating a hierarchy of rights.

The rights included in the Charter were selected not because of their importance, but rather because of the way they were to be defined and enforced. Where the likely violator of a human right is the state, and where enforcement is largely by way of prohibition of state action, the best instrument for enforcing the right is the judicial system. Conversely, where the likely violation of a human right stems from the operation of the economic and social systems, then the best instruments for enforcing these rights are the legislative, executive, and administrative arms of government.

I contend that in the protection of human rights there will be instances where rights collide, and that there will need to be a mediating mechanism. Section 1 of the Charter can serve such a role. Section 33, the "notwithstanding" clause, can also serve such a role. But neither can serve the role adequately unless it is made clear to the public how each functions and what its purpose is. The public cannot be properly informed if the language used in Charter discourse refers to a "suspension of rights" 3 or a weighing of the "relative importance of rights 
and legislated social purposes"4 when either section 1 or section 33 is invoked.

To make my point I will embark upon a more detailed review of human rights as this term is understood in the political and judicial world of Western democracies, and particularly in Canada.

\section{Developing Human Rights - A Brief History}

In Canada, we are heirs to many proud traditions. The way we govern ourselves and think about government has come to us from the great traditions of Greece and Rome and from the Near East. ${ }^{5}$ These traditions settled in Western Europe and came to Canada with the early settlers from Britain and France. ${ }^{6}$ After the fall of New France in 1759 and 1760, British ideas of government and justice came to dominate the way that Canadians think about how they govern themselves. ${ }^{7}$

In this way the history of Britain, and British thought about governments and rights, has become part of our history. The British developed from a feudal system in the Middle Ages, to the divine right of kings, to parliamentary democracy where citizens began to have rights and freedoms. Thomas Hobbes contended that for an ordinary person the greatest freedoms were to have food and shelter and to be free from threats to life, well-being, and property. ${ }^{8}$ These freedoms were necessary so that a citizen could raise a family. He said (to oversimplify) that in order to enjoy basic rights, the citizen had to give up his rights to freedom of speech, freedom of religion, and many other freedoms in favour of the monarch or central authority. John Locke essentially agreed with Hobbes but said that it was not necessary for the monarch or central authority to have all of these powers in order to guarantee to the citizen the basic freedoms. The citizen should be able to enjoy these basic freedoms and participate in the government by the monarch or central authority. ${ }^{9}$

For the last 350 years societies in Britain, much of Western Europe, the United States, Canada, and elsewhere have been in a debate on how much authority must be exercised by the monarch or central authority and how much should remain with the people. This is the enduring question at the root of all democratic governments. Citizens cannot enjoy unrestricted freedom - unrestricted rights. Rights collide, freedoms collide.

What we have witnessed over time is the gradual development of a consciousness that people, because they are human, have certain rights: "inalienable rights" as they are sometimes called, though a great number of them seem to have been alienated at one time or another. This gradual development came in part as a result of writers such as Voltaire ${ }^{10}$ and Rousseau in France, Thomas Jefferson in the United States, and the Englishman Tom Paine, who in 1791 and 1792 wrote a seminal work called The Rights of Man. ${ }^{11}$ Bills of Rights emerged in Britain and the U.S. In Britain, the Glorious Revolution of 1688 culminated with the Bill of Rights. ${ }^{12}$ The United States in 1789 produced a Bill of Rights, the name given to the first ten amendments of the U.S. Constitution. ${ }^{13}$

During the nineteenth century, ideas of human rights gradually expanded. Then came the twentieth century and World War I. This was a cataclysmic event. It toppled some of the great monarchies of the world, including the German Empire, the Austro-Hungarian Empire, and the Russian Empire. It also gave to many who fought and survived a belief that somehow they had earned a right to greater freedom, whatever that might mean.

The years that followed World War I, and particularly the years of the world-wide depression, were years of great economic privation and, accordingly, years when traditional human rights were frequently ignored. Large numbers of people throughout the globe had great difficulty attaining the "Hobbes basics" of food, shelter and the ability to rear a family. It became all too evident that if there were not acceptable minimums of these basic freedoms, the public was not prepared to defend traditional human rights against those who promised food, shelter, and safety. 
World War II followed. In his State of the Union Address to Congress of 1941, which has come to be known as the "Four Freedoms speech," President Franklin D. Roosevelt set out four essential freedoms: freedom of speech, freedom of religion, freedom from fear, and freedom from want. ${ }^{14} \mathrm{He}$ attempted to include in one broad definition of freedom, those freedoms of the human spirit articulated by philosophers from Locke to Voltaire to Jefferson to Paine with the elemental freedoms that I have called the "Hobbes basics." These ideas of what freedoms we should seek in a postwar world gained support from the oft-discussed visionary war aims that sought to shape the Second World War as a war for human freedom.

The immediate post-World War II years commenced a new era in rights and freedoms. For much of the Western world there was economic stability and comparative material prosperity, fuelled by the efforts to wage war and by a relatively enlightened approach to post-war reconstruction. The basics of food and shelter, as described by Hobbes, were met, thus allowing the concept of other rights and freedoms to flourish.

In 1945 the United Nations was created after delegates of fifty nations met in San Francisco for the United Nations Conference on International Organization. Its overarching objective was to attempt to build a framework that would preserve international peace. Its first and arguably most important document was the Universal Declaration of Human Rights, ${ }^{15}$ signed on December 10, 1948 by forty-eight states. The Universal Declaration contains thirty articles which articulate international human rights standards. Following the signing of the Declaration, the International Covenant on Civil and Political Rights, ${ }^{16}$ and the International Covenant on Economic, Social and Cultural Rights, ${ }^{17}$ which elaborate on the rights articulated in the Universal Declaration, were signed. Together, the three documents comprise the International Bill of Human Rights.

The very substantial ratification of these declarations and covenants by a large number of countries so that the declarations and covenants entered into force, at least as ideals, in- dicated a growing acceptance across the world of the willingness of governments to provide - to the extent they could given other competing needs and rights - a minimal standard of freedom of speech, freedom of thought and religion, freedom from fear, and freedom from want. This process of articulation and acceptance continues until this day.

\section{Enforcing Human Rights}

Declarations and covenants set out objectives to which governments, with greater or lesser levels of sincerity, commit themselves. Declarations and covenants are far from selfenforcing. Whether they bring about any practical changes depends upon the willingness of those with power to design effective internal mechanisms to ensure their protection and enforcement. There is, of course, another very important element. As more countries become democratic, it is critical that any infringements of basic, necessary rights in the interest of, for example, security against external and "terrorist" foes, or in the interest of maintaining a viable economy, or in the interest of preserving a religion or culture, be carefully monitored. The public, and through the public their governments, must be willing to protect basic human rights even in light of other issues of importance.

Through their governments, countries have chosen various instruments for the enforcement of rights. If we divide governmental institutions broadly into legislative, executive and judicial institutions, we note that all have played a major role, both in the direct enforcement of rights and in stimulating public discussion, which allows citizens to understand and appreciate the issues associated with their rights and freedoms.

If we look about the world to see where the most progress has been made in protecting and fostering the four freedoms articulated by Roosevelt, we would, I think, give high marks to countries such as Norway, Sweden, Denmark, Holland, New Zealand, and perhaps Britain, Canada, Australia, France, Switzerland, the United States, and others. Some of these countries have relied heavily on actions by the legislative and executive branches of their govern- 
ments, and some have relied more heavily on the judicial branch to protect at least two or perhaps three of the four freedoms. All have felt that if there was to be an acceptable measure of freedom from economic want, and the fear which flows from economic want, then there were major roles for the legislative and executive branches of government. Based upon results throughout the world, it is difficult to conclude that any one mix of instruments of enforcement is markedly superior to any other.

Our approach in Canada is instructive. We sought, through the Constitution Act, 1867, to give to Canada a constitution "similar in Principle to that of the United Kingdom." ${ }^{18}$ We relied upon the practices of the United Kingdom to establish a regime of rights and freedoms for our citizens. As we, along with the rest of the world, considered and discussed ways to improve our record of ensuring for our citizens an appropriate level of rights and freedoms, and considered how we might implement the declarations and covenants of the United Nations which we had ratified, we passed, for example, the Canadian Bill of Rights ${ }^{19}$ in 1960 and the Canadian Human Rights Act ${ }^{20}$ in 1977, and several provinces passed their own provincial human rights acts. But it became clear to many Canadians that our regimes for protecting human rights were not fully effective. They depended heavily on the benevolence and understanding of a majority of the citizens. Without specific mechanisms for the protection and enforcement of rights, our citizens were essentially left to their own devices.

It is true that throughout history a good place to start in protecting rights and freedoms has been to protect them for a majority of the citizens. But clearly that is not enough. Minorities are frequently at risk from intolerant majorities. The idea developed that we ought to provide additional protection for minorities and for those who are disadvantaged, at least to the extent that they lack power and influence in political and economic circles, by giving a special role to the courts to intervene where they believe that the majority, acting through the legislature and the executive, have unfairly deprived the powerless of their rights to freedom of speech, to freedom of religion, and to freedom from fear of state power - the "protection against the state" freedoms. We recognized that this was fundamentally a defensive position. It was recognized that courts were ill-equipped to protect citizens from fears which might arise because of the operation of economic power by non-government entities, and want stemming from their unfavourable economic position the "protection against economic adversity" freedoms.

So, a body of rights and freedoms was entrenched in our Constitution Act, 1982 - the Canadian Charter of Rights and Freedoms - and the courts were given a special role in protecting the powerless against the breach of these rights and freedoms by the legislative and executive arms of government.

In selecting some rights and freedoms for inclusion in the Charter, there was no intention to create a hierarchy of rights in the sense that the rights included in that document were more important than others. Rather, the rights and freedoms chosen for inclusion in the Charter were selected because it was reasonable to give the courts a role in their enforcement. On the other hand, it was felt that the courts were ill equipped to enforce freedoms from fear and want. ${ }^{21}$ The enforcement of these rights would remain with the legislative and executive branches of government.

It should be noted that the thought was to use the courts to protect the rights of the powerless and the disadvantaged by entrenching those rights in the Charter. That, I think, was what the Charter of Rights and Freedoms was designed to do. It was not designed to provide that a Charter freedom was more important than the freedom from (say) want. Nor was the Charter intended to give to the courts any general supervisory role over the way in which legislatures and executives operate to redistribute wealth and power in the society, except to the extent that the courts were to protect the inherent fairness of the decision-making processes in a democratic society.

The Charter was not intended and should not be interpreted to give the courts a role in 
the distribution of the economic power in society. Thus, the Charter right of an individual to "security of the person" 22 does not trump the rights of other groups of persons. Rights and freedoms affecting distribution of economic wealth and power were not to fall to the courts to determine, except to the extent that a person or persons may have been subject to discrimination based upon race, ethnic origin, or like categories enumerated in section $15 .{ }^{23}$

\section{Dealing with Collisions between Rights}

The Constitution Act, 1982 which brought us the Charter contemplated that there would inevitably be collisions between rights. Therefore, rights were articulated in broad-brush terms and the language used was intended to set out principles and values rather than particular answers to precise problems. It was recognized that in any dynamic democratic society there should be room for growth of ideas, as there would over time be changes in the public's thinking on rights and freedoms. Therefore, there are several provisions in the Charter which allow for changes in approaches over the years. Section 1 talks about limiting rights and freedoms to the extent that the limits can be "demonstrably justified in a free and democratic society." ${ }^{24}$ Shortly put, this means that it is up to the legislative and executive branches to justify the limitation of any rights set out in the Charter. Limitations must be "reasonable" in the eyes of the court. It is the court that decides the scope of a "free and democratic society" at any given time in our history. Similarly, in section 7 of the Charter, persons are not to be deprived of rights "except in accordance with the principles of fundamental justice." ${ }^{25}$ Here again it is the courts that are to define what are the principles of fundamental justice - concepts that evolve with time.

We have noted that the Charter does not purport to include many of the key rights and freedoms set out in the International Bill of Rights. Nor, in my view, does the Charter in any way indicate that the rights and freedoms included are more important than other rights to be enjoyed by citizens, notably rights to freedom from fear and freedom from want, where those rights might be infringed by entities which are not governments. The Charter limits only governments. I do not think that it was ever intended to suggest that only governments threaten the freedom of citizens.

So it is entirely likely that the rights set out in the Charter will come into conflict with other equally important rights which are the responsibility of the legislative and executive arms of government to protect. This eventuality was contemplated by the drafters of the Charter when they included section 33. This "notwithstanding" section, as it has come to be known, allows a Parliament or a legislature to declare that it can act notwithstanding the provisions included in section 2 or in sections 7 to 15 of the Charter, and this includes decisions of the court about breaches of those sections. In other words, if Parliament or the legislature decides that the breach of a Charter right or freedom infringes another right or freedom not set out in the Charter, or where political or other circumstances are such that compliance with a Charter right will produce undesirable results, Parliament or the legislature may act "notwithstanding" the Charter right or notwithstanding a decision of a court that the Charter right has been breached. ${ }^{26}$ This seems to me to be an elegant way to deal with the inevitable collisions that will occur between rights which we seek to protect through legislative and executive action, and rights which we seek to protect through judicial action. Based upon historical precedent, a strong case can be made for the use of all three arms of government in protecting rights and freedoms.

I think it is important that we formulate the problem as one of protecting the rights and freedoms of citizens - some of the these rights and freedoms are set out in the Charter of Rights and Freedoms, some of the rights are set out in other documents including declarations and covenants of the United Nations, ratified by Canada, and some are part of our unwritten constitution. Among these rights there is not a hierarchy of more important and less important, and it is inevitable that rights will come 
into conflict with one another. The Charter should be viewed not as creating a hierarchy of rights, but rather as articulating those rights for which the courts have an appropriate role in enforcement. Viewed from this perspective, it will be seen that arguments based on slogans such as "a right is a right is a right," and suggesting that a right set out in a charter is a right but that a right to freedom from want as set out in the United Nations International Covenant on Economic, Social and Cultural Rights is not a right, are without force.

\section{Responding to Professor Whyte's Article}

Professor Whyte's very able article on the future of the Charter's "notwithstanding" clause is noteworthy for the power of the implicit as well as the explicit arguments it makes. ${ }^{27}$ In this article, he quotes Professor Waldron as setting out two interpretations of section 33. One interpretation is that the section exists to allow the legislature or the executive to decide that a rights breach is not as important as a particular governmental policy. Another is that a legislature may disagree with the court's interpretation of rights and may therefore wish to legislate in the face of judicial conceptions of rights. ${ }^{28}$ He pointedly does not include a case where the conflict for the legislative and executive branches of government is over the relative importance of a Charter versus a non-Charter right. There are circumstances where it is widely accepted by the legislative and executive branches of government, and the public, that a decision must be made about rights that conflicts with a judicial decision about a Charter breach. The suggestion in Professor Whyte's article that some rights, because they are not included in the Charter, are somehow less important than the rights included in the Charter is, in my view, wrong for the reasons alluded to above. To repeat, there are rights which were not included in the Charter because they were not on the list of rights where courts have a useful role to play in their enforcement. One thinks of the Hobbesian basics of rights to food and shelter and the rights to rear one's family. But this in no way suggests that these rights and others like them - I would include a right to basic medical care - are less important than some rights included in the Charter. This is not simply a case of using section 33 to achieve "governmental policy" (to use Professor Waldron's words). ${ }^{29}$ Rather it is a case of using section 33 to protect a fundamental right that is not included in the Charter.

It may be that section 33 is not the correct instrument to deal with the situation that arises when a Charter right collides with a nonCharter right. But that situation cannot be fairly dealt with by denying the existence of the nonCharter right, and therefore denying the necessity of the democratic majority suspending a Charter right where it serves to undermine and possibly destroy an equally important nonCharter right.

Because of the success of the Charter enthusiasts in propagating the view that if a right was not in the Charter then it was somehow not a right, attempts have been made to explicitly articulate in the Constitution a statement of other rights, notably social and economic rights, so that they would have similar cachet as Charter rights. The proposal to introduce into the Charlottetown Accord (1992) a social and economic charter, which would not be justiciable, sought to deal with those who persist in the view that our basic rights come from the historical events which happened in the United States in 1789, and not the rights represented by the history of Britain and Canada before and after the United States Bill of Rights. In 1982, rights to provincial equalization payments were articulated in section 36 of the Constitution Act and made non-justiciable. The attempt at Charlottetown to add a constitutional statement of social and economic rights, which would similarly be nonjusticiable, failed for other reasons. But that lack of success in no way suggests that these rights did not or do not exist, or that a Canada acceptable to Canadians could long survive without them.

It is not lawyers who tell us what our constitution is. It is not politicians who tell us what our constitution is. In a democratic society it is citizens who tell us what our constitution is, and I believe they have told us that our constitution, in its complete written and unwrit- 
ten form, includes, at some level, freedom of speech, freedom of religion, freedom from fear, and freedom from want.

One can only be amused by the tendency of legal scholars to characterize freedom of speech and freedom of religion as "fundamental" rights and freedom from want as not a "fundamental" freedom. In the 2008 earthquake in China by an act of nature, millions were deprived of their basic human rights. ${ }^{30}$ The Chinese government marshalled emergency aid, for which it was widely commended and widely criticized - the fate of most governments. But among all the critical comments, I have detected none which deal with its prohibiting advertising to sell cigarettes, or its refusal to allow shops (when they were rebuilt) to open on Sunday, or its prohibition of students carrying ceremonial daggers when they go to school (as soon as they have a school to go to). Another definition of "fundamental freedoms" is at work; and should be.

It is readily conceded that unless there is a good measure of the fundamental freedoms referred to in the Charter, democracy will be imperilled. But, equally, unless there is a good measure of economic equality so as to reduce the fear and want of ordinary citizens, democracy will be imperilled. Roosevelt got it right.

Our task is to devise a system which will recognize these realities. It might be argued that the "notwithstanding" clause could be used to protect policy positions which could not fairly be called freedoms. And that must be conceded. The courts, in their zeal to protect Charter rights, could ignore what would be widely recognized as non-Charter rights. That too must be conceded.

If the "notwithstanding" clause is not the right instrument to mediate the clash of Charter and non-Charter rights, it would be helpful if scholars would suggest other appropriate instruments.

Perhaps an amendment of the wording of the "notwithstanding" clause would be helpful. Perhaps another attempt to include in the Constitution a statement of non-justiciable social and economic rights would be desirable in order to remind the courts of the existence of important rights whose enforcement has been assigned to other arms of government.

Whatever may be attempted, it is my view that it would be helpful if scholars took pains to formulate the public issues which will inevitably arise in a context of the articulation and enforcement of all human rights which citizens can reasonably expect to enjoy in a free and democratic society.

\section{Notes}

* The Honourable Allan E. Blakeney was Premier of Saskatchewan from 1971 to 1982 and is a signatory of Canada's patriated constitution. He is now a visiting scholar at the University of Saskatchewan, College of Law and recently published his memoirs: An Honourable Calling (Toronto: University of Toronto Press, 2008).

1 John Whyte, "Sometimes Constitutions are Made in the Streets: the Future of the Charter's Notwithstanding Clause" (2007) 16 Constitutional Forum constitutionnel 79.

2 Part I of the Constitution Act, 1982, being Schedule B to the Canada Act 1982 (U.K.), 1982, c. 11.

3 Supra note 1 at 80.

4 "Under section 1, governments are required to place their rights calculations before a court and to show how they have weighed the relative importance of rights and legislated social purposes." Ibid. at 85.

5 See Richard Wollheim, "Democracy" (1958) 19:2 Journal of the History of Ideas 225.

6 See Law Reform Commission of Saskatchewan, The Status of English Statute Law in Saskatchewan (Saskatoon: Law Reform Commission of Saskatchewan, 1990).

7 See Constitution Act, 1867 (U.K.), 30 \& 31 Vict., c. 3, Preamble. British dominance of Canadian constitutionalism is enunciated in the constitution itself where the preamble states: "Whereas the Provinces of Canada, Nova Scotia, and New Brunswick have expressed their Desire to be federally united into One Dominion under the Crown of the United Kingdom of Great Britain and Ireland, with a Constitution similar in Principle to that of the United Kingdom" (emphasis added).

8 "[W]hatsoever is so tyed, or environed, as it cannot move, but within a certain space, which space is determined by the opposition of some externall body, we say it hath not Liberty to go 
further.... A FREE-MAN, is he, that in those things, which by his strength and wit he is able to do, is not hindred to doe what he has a will to.... [A]s men, for the atteyning of peace, and conservation of themselves thereby, have made an Artificiall Man, which we call a Commonwealth; so also have they made Artificiall Chains, called Civill Lawes, which they themselves, by mutuall covenants, have fastned at one end, to the lips of that Man, or Assembly, to whom they have given the Soveraigne Power; and at the other end to their own Ears. These Bonds in their own nature but weak, may neverthelesse be made to hold, by the danger, though not by the difficulty of breaking them.... The Liberty of a Subject, lyeth therefore only in those things, which in regulating their actions, the Soveraign hath praetermitted: such as is the Liberty to buy, and sell, and otherwise contract with one another; to choose their own aboad, their own diet, their own trade of life, and institute their children as they themselves think fit; \& the like.... The Libertie ... is not the Libertie of Particular men; but the Libertie of the Common-wealth: which is the same with that, which every man then should have, if there were no Civil Laws, nor Common-wealth at all. And the effects of it also be the same. For as amongst masterlesse men, there is perpetuall war, of every man against his neighbour; no inheritance, to transmit the Son, nor to expect from the Father; no propriety of Goods, or Lands; no security; but a full and absolute Libertie in every Particular man: So in States, and Common-wealths not dependent on one another, every Common-wealth, (not every man) has an absolute Libertie, to doe which it shall judge (that is to say, what that Man, or Assemblie that representeth it, shall judge) most conducing to their benefit." Thomas Hobbes, Leviathan, revised student ed. by Richard Tuck (Cambridge: Cambridge University Press, 1996) at 145-149 (emphasis in original).

"The great end of men's entering into society being the enjoyment of their properties [Locke defines properties as 'lives, liberties, and estates'] in peace and safety, and the great instrument and means of that being the laws established in that society; the first and fundamental positive law of all commonwealths is the establishing of the legislative power; as the first and fundamental natural law, which is to govern even the legislative itself, is the preservation of the society, and (as far as will consist with the public good) of every person in it.... [The legislative] power, in the utmost bounds of it, is limited to the public good of the society. It is a power that hath no other end but preservation, and therefore can never have a right to destroy, enslave, or designedly to impoverish the subjects." Paul E. Sigmund, ed., The Selected Political Writings of John Locke: Texts, Background Selections, Sources, Interpretations (New York: W.W. Norton, 2005) at 72-76.

10 In a letter to M. Damilaville, 1 March 1765, Voltaire reacts to a publication finding that a man Voltaire had believed innocent of parricide and who had been publicly executed on a wheel, had indeed been innocent, but who, in Voltaire's opinion, had been killed in consequence of religious fanaticism. Voltaire revealingly writes of the virtues of a philosopher, reflecting in a simple statement his rather comprehensive views on those virtues that enable free society: "Like the sage of Montbar, like the sage of Voré, he knows how to make the land fruitful and those who dwell on it happier. The real philosopher clears uncultivated ground, adds to the number of plows and, so, to the number of inhabitants: employs and enriches the poor: encourages marriages and finds a home for the orphan: does not grumble at necessary taxes, and puts the agriculturist in a condition to pay them promptly. $\mathrm{He}$ expects nothing from others, and does them all the good he can. He has a horror of hypocrisy, but he pities the superstitious: and, finally, he knows how to be a friend." Voltaire also wrote of the British Parliamentary model: "Here follows a more essential difference between Rome and England, which throws the advantage entirely on the side of the latter; namely, that the civil wars of Rome ended in slavery, and those of the English in liberty. The English are the only people on earth who have been able to prescribe limits to the power of kings by resisting them, and who, by a series of struggles, have at length established that wise and happy form of government where the prince is all-powerful to do good, and at the same time is restrained from committing evil; where the nobles are great without insolence or lordly power, and the people share in the government without confusion." Ben Ray Redman, ed., The Portable Voltaire (New York: Penguin, 1977) at $508,513$.

11 Thomas Paine, "The Rights of Man, Parts I \& II" in Bruce Kuklick, ed., Paine: Political Writings (Cambridge: Cambridge University Press, 2000) 57, 155.

12 An Act declaering the Rights and Liberties of the Subject and Setleing the Succession of the Crowne, (U.K.), 16881 Will. \& Mar. Sess. 2 c. 2 (known colloquially as the English Bill of Rights 1689). 
13 U.S. Const. amend. I-X.

14 President Franklin D. Roosevelt, Annual Message to Congress on the State of the Union, January 6, 1941.

15 Charter of the United Nations, 26 June 1945, Can. T.S. 1945 No. 7 [UN Charter]; and see Universal Declaration of Human Rights, GA Res. 217(III), UN GAOR, 3d Sess., Supp. No. 13, UN Doc. A/810 (1948); and see Statute of the International Court of Justice 26 June 1945, Can. T.S. 1945 No. 7 (annexed to the UN Charter). The UN Charter provides that member states fall within the purview of the International Court of Justice. 16 December 1966, 999 U.N.T.S. 171, Can.T.S. 1976 No. 47 (entered into force 23 March 1976, accession by Canada 19 May 1976); Optional Protocol to the International Covenant on Civil and Political Rights, 16 December 1966, 999 U.N.T.S. 171, Can.T.S. 1976 No. 47 (entered into force 23 March 1976, accession by Canada 19 May 1976).

1716 December 1966, 993 U.N.T.S. 3, Can.T.S. 1976 No. 46 (entered into force 3 January 1976, accession by Canada 19 May 1976).

18 Supra note 7.

19 S.C. 1960, c. 44.

20 R.S.C. 1985 , c. H-6.

21 Supra note 2 at s. 2. As such the fundamental freedoms listed in section 2 of the Charter are not an exhaustive list. Also note section 26 which specifically states that the guarantee of rights and freedoms in the Charter should "not be construed as denying the existence of any other rights or freedoms that exist in Canada."

22 Ibid. at s. 7.

$23 \mathrm{Ibid}$. at s. 15(1): "Every individual is equal before and under the law and has the right to the equal protection and equal benefit of the law without discrimination and, in particular, without discrimination based on race, national or ethnic origin, colour, religion, sex, age or mental or physical disability."

Ibid. at s. 1.

Ibid. at s. 7.

Ibid. at s. 33(1): "Parliament or the legislature of a province may expressly declare in an Act of Parliament or of the legislature, as the case may be, that the Act or a provision thereof shall operate notwithstanding a provision included in section 2 or sections 7 to 15 of this Charter." A declaration shall operate for at most five years, but it can be extended by re-enactment: ibid. at ss. 33(3)-(4). Supra note 1 at 79-80.

28 Ibid., citing Jeremy Waldron, "Some Models of Dialogue Between Judges and Legislators" in
Grant Huscroft \& Ian Brodie, eds., Constitutionalism in the Charter Era (Markham, ON: LexisNexis Canada, 2004) 7 at 36 ["Waldron"]. 29 Professor Whyte summarizes Jeremy Waldron's claim that the latter class of rights conflicts are "rights misgivings: the executive or the legislature believes that in a particular situation rights claims are simply not as important as achieving governmental policy and, therefore, should not be allowed." Supra note 1 at 79-80 (emphasis added). Professor Waldron writes: "I think the trouble with the 'notwithstanding' clause is that it requires the legislators to present themselves as having rights-misgivings, when in fact they may not be having rights-misgivings ... but rather attempting to legislate in the face of judicial conceptions of rights that they disagree with." Waldron, supra note 28 at 37. Professor Waldron is responding to Jeffrey Goldsworthy's claim that the notwithstanding clause was designed to "enable legislatures to override judicial interpretations or applications of Charter rights with which they reasonably disagree." Jeffrey Goldsworthy, "Judicial Review, Legislative Override, and Democracy” (2003) 38 Wake Forest Law Review 451 at 452 . Note that Professor Goldsworthy is of the opinion that the section 33 "notwithstanding" clause is not required for legislatures to balance competing rights with protected rights, believing instead that a proper interpretation of section 1 provides for the possibility of a need for balance between competing rights claims.

30 An 8.0 magnitude earthquake hit China's southwestern Sichuan province on May 12, 2008 and is estimated to have killed nearly 70,000 people, injured another 375,000 (approximately), and rendered homeless an estimated 4.8 to 11 million individuals. 